\title{
Impact of meteorological variables on water quality parameters of a reservoir and ecological filtration system
}

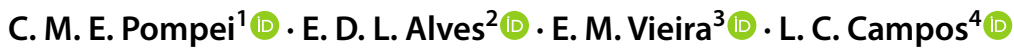

Received: 25 March 2019 / Revised: 29 August 2019 / Accepted: 24 September 2019 / Published online: 5 October 2019

(c) The Author(s) 2019

\begin{abstract}
Recently, special attention has been given to low-cost technologies for water treatment, with the aim of serving remote communities and thus enabling everyone to have access to drinking water and basic sanitation. In that context, the ecological filter is an alternative for treating water for human consumption. Some studies show that climate change and meteorological parameters can influence the water quality of water bodies and the water supply system. However, most of the papers deal with model projections and therefore do not show real situations. The aim of this study was to determine the impact of meteorological variables (e.g. atmospheric pressure, evaporation, wind speed, radiation, precipitation) on the physicochemical and biological parameters (e.g. turbidity, apparent colour, pH, total coliforms, Escherichia coli) of Lobo reservoir water treated by 22 ecological filters during a period of 4 months. Statistically significant correlations were found between the water from the Lobo reservoir and the weather variables, and between the water quality parameters of the 22 ecological filters and the average weather variables. The results from the statistical analysis indicate that climatic variations may influence treatment performance.
\end{abstract}

Keywords Ecological filtration $\cdot$ Water treatment $\cdot$ Water quality parameters $\cdot$ Meteorological conditions

Editorial responsibility: M. Abbaspour.

Electronic supplementary material The online version of this article (https://doi.org/10.1007/s13762-019-02552-8) contains supplementary material, which is available to authorized users.

L. C. Campos

1.campos@ucl.ac.uk

1 Water Resources and Applied Ecology Center, São Carlos School of Engineering, University of São Paulo, Avenida Trabalhador São Carlense 400, Caixa Postal 292, São Carlos, SP 13560-970, Brazil

2 Instituto Federal de Educação, Ciência e Tecnologia Goiano, Campus Ceres, Rod. 154, Km 3, Zona Rural, Ceres, Goiás 76300-000, Brazil

3 Department of Chemistry and Molecular Physics, São Carlos Institute of Chemistry, University of São Paulo, Avenida Trabalhador São Carlense 400, Caixa Postal 780, São Carlos, SP 13560-970, Brazil

4 Department of Civil, Environmental and Geomatic Engineering, University College London, Chadwick Building, Room GM11, Gower Street, London WC1E 6BT, UK

\section{Introduction}

Ecological filtration is a new nomenclature suggested by Nakamoto (2008) for slow sand filtration. The new name is derived from the presence of a biofilm that forms on top of the sand filter and the action of the various microorganisms that make up a food chain, which are essential to water purification. "Ecological filter" involves the action of algae, cyanobacteria, bacteria, protozoa and small invertebrates in the process (Huisman and Wood 1974; Nakamoto 2008). The idea of an ecological purification system for drinking water arose from an observation of phytoplankton at the Lobo reservoir in 1974 (Nakamoto 2011) in São Paulo, Brazil. Amongst the various water treatment technologies, slow sand filtration or ecological filtration is very attractive as it does not require the application of chemicals, nor does it require skilled labour. Additionally, it also provides excellent removal of pathogenic organisms, including Giardia and Cryptosporidium (Bellamy et al. 1985; Haarhoff and Cleasby 1991), as well as complex organic compounds such as certain drugs (Erba et al. 2014; Pompei et al. 2017; Li et al. 2018). 
The ecological filter operates with a low filtration rate (i.e. filtration speed), resulting in high retention time of the water above and within the sand bed. As a result of the high retention time, an intense biological activity develops in the upper layers of the filter bed; this then contributes to the development of the schmutzdecke (Campos et al. 2002).

The quality parameters of surface water vary with the environmental conditions such as solar radiation, precipitation, humidity, atmospheric pressure and temperature (Delpla et al. 2009). For example, lower precipitation results in lower runoffs into water bodies and less dilution, causing higher concentrations downstream of point discharges of wastewater. This affects efforts to improve water quality standards or meet the directives of water quality treatment works (WTWs) (Whitehead et al. 2009) and, consequently, the water supply (Mujere and Moyce 2017). This influence can be natural and without harmful consequences, but some changes in the climate can affect the water quality of reservoirs, putting in risk the water supply quality (Murdoch et al. 2000; Mujere and Moyce 2017).

At the Lobo reservoir, Calijuri and Tundisi (1990) identified deforestation, domestic sewage disposal and fertilizers used in some agricultural areas, as human activities causing environmental changes. Tundisi et al. (2004) evaluated the impacts of the passage of cold fronts on the vertical structure of the Lobo reservoir through assessment of the changes in physico-chemical and biological water characteristics. They found that during periods of incidence of cold fronts the reservoir presented vertical mixing. However, a period of stability was followed by thermal, chemical and biological stratification after the dissipation of the cold fronts.

Samu et al. (2013) analysed the influence of the meteorological variables in five lakes in Hungary. They found that the maximum concentration values of water quality parameters occurred more frequently when the global solar radiation, atmospheric pressure and the precipitation were lower than when the relative humidity was high. Also, at the Kasumigaura Lake, Japan, Fukushima et al. (1998) investigated the relationship between weather conditions and water quality; they quantitatively predicted the change in water quality due to variations in weather conditions. It was observed that an increase in air temperature resulted in the deterioration of the lake water quality.

Some studies have been conducted to examine how the climate change affects the water quality of water bodies (Fukushima et al. 1998; Murdoch et al. 2000; Tundisi et al. 2004; Prathumratana et al. 2008; Delpla et al. 2009; Whitehead et al. 2009) and water supply systems (Delpla et al. 2009; Rajib et al. 2012). Additionally, a comprehensive review of the potential impacts of climate change on surface water quality was published by Whitehead et al. (2009). However, most of these studies deal with model projections, simulating climate changes and evaluating their impacts (Fukushima et al. 1998; Jones and Page 2001). Besides the long-term climate changes, variations of some meteorological parameters can influence the performance of the treatment process and the final quality of the water treated for potable purposes. Therefore, there are no studies that have evaluated the relationship between meteorological variables and reservoir water quality and ecological filtration performance. The novelty of this study is the investigation of the relationship between the empirical data of the Lobo reservoir water quality, meteorological variables and ecological filtration water quality.

The knowledge of the correlation between these parameters and the treated water quality may help system operation and planning, particularly for ecological filters which are mainly biological processes. Thus, this study aimed to determine the impact of meteorological variables on the physico-chemical and biological water parameters of the Lobo reservoir, São Paulo, Brazil, treated by 22 ecological filters, from September to December 2013.

\section{Materials and methods}

\section{Study site}

The Lobo reservoir (Fig. 1a) is located between the municipal districts of Itirapina and Brotas, São Paulo, Brazil. It was originally built for generating electrical energy in 1936 and has been part of the University of São Paulo's research pool since 1971, where investigations on several ecological aspects affecting the hydrodynamic, chemical and biological processes operating within this shallow and man-made lake have taken place (Rodríguez and Matsumura-Tundisi 2000).

The location of the 22 ecological filters is shown in Fig. 1a. The water that fed the 22 ecological filters (Fig. 1b) was pumped from the Lobo reservoir (latitude $-22.170^{\circ}$ and longitude $-47.899^{\circ}$ ), located at Itirapina city, São Paulo, Brazil, to a constant level box.

\section{Construction of the ecological filters}

Twenty-two parallel and identical ecological filters were constructed in polyvinyl chloride (PVC). Each ecological filter had a diameter of $25 \mathrm{~cm}$ and height of $72 \mathrm{~cm}$. The support layer in each filter was formed by three gravel layers, with a total height of $15 \mathrm{~cm}$, with grain size ranging from 12.5 to $1.41 \mathrm{~mm}$. The sand bed layer had $30 \mathrm{~cm}$ height with grain size between 1.0 and $0.08 \mathrm{~mm}$. The sand uniformity coefficient was between 2 and 3, and the effective diameter was $0.25 \mathrm{~mm}$ (Bellamy et al. 1985). On average, the filtration rate used for the filters was $3 \mathrm{~m}^{3} \mathrm{~m}^{-2}$ day $^{-1}$. 


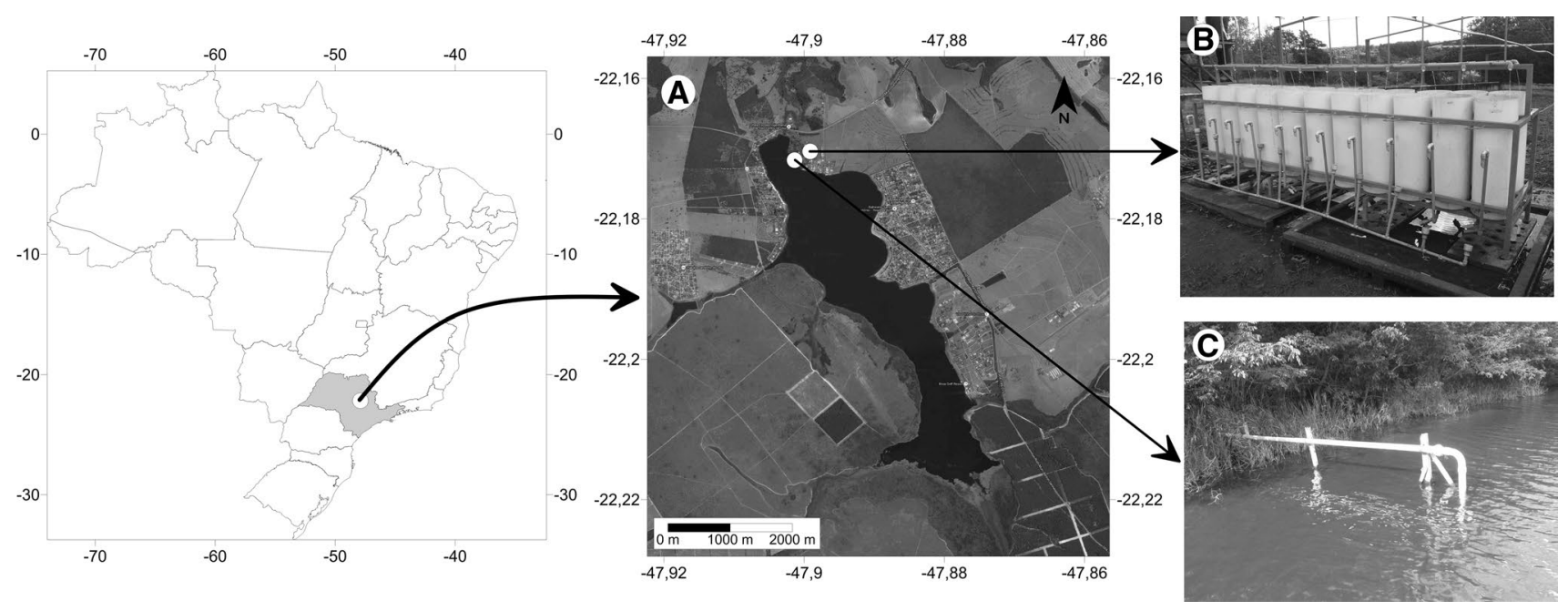

Fig. 1 Location of a the Lobo reservoir, $\mathbf{b}$ the ecological filters and $\mathbf{c}$ the water intake

\section{Sampling and analysis of water quality parameters}

Filters were operated continuously from September to December 2013 (4 months), and water samples $(100 \mathrm{~mL})$ were collected from influent and effluent water of each ecological filter three times per week, totalling 30 measurements. Samples were collected in flasks $(100 \mathrm{~mL})$, transported manually using a carrier bag to the laboratory and immediately analysed.

Turbidity and apparent colour were measured in situ using a HACH DR 2000 spectrophotometer, setting wavelengths in UV750 and UV455, respectively. Temperature $\left({ }^{\circ} \mathrm{C}\right)$ was also measured in situ. True colour was measured after filtering the water sample through a $0.45 \mu \mathrm{m}$ membrane (Millipore, cellulose ester, $90 \mathrm{~mm}$ diameter) and measured by the spectrophotometer using UV455 (HACH DR 2000). The pH was measured by a $\mathrm{pH}$ meter B374-Micronal—while temperature, conductivity $\left(\mu \mathrm{cm}^{-1}\right)$ and total dissolved solids (TDS) $\left(\mathrm{mg} \mathrm{L}^{-1}\right)$ were measured using an Orion multiparametermodel 145. Dissolved oxygen (DO) $\left(\mathrm{mg} \mathrm{L}^{-1}\right)$ was measured using an oximeter YSI, Yellow Springs Incorporated (Ohio, USA), model 55-25 FT. Total coliforms and E. coli were measured using a Colilert ${ }^{\circledR}$ kit. For total coliforms (MNP) and $E$. coli (MNP) counting, water samples from the Lobo reservoir were diluted with Milli-Q water at a concentration of 1:500.

\section{Meteorological variables}

Meteorological data were collected daily, three times per day, at the climatological station from the Centre for Water Resources and Environmental Studies (CRHEA in
Table 1 Water quality parameters measured in the Lobo reservoir water and in the filtered water by the 22 ecological filters, showing minimum and maximum, average and standard deviation values

\begin{tabular}{|c|c|c|c|c|c|c|c|c|}
\hline \multirow[t]{2}{*}{ Water quality parameters } & \multicolumn{4}{|l|}{ Reservoir } & \multicolumn{4}{|c|}{ Ecological filters } \\
\hline & Min & Max & Average & SD & Min & Max & Average & SD \\
\hline $\operatorname{TDS}\left(\mathrm{mg} \mathrm{L}^{-1}\right)$ & 7.00 & 9.00 & 8.03 & 0.32 & 1.00 & 28.00 & 8.89 & 1.03 \\
\hline Conductivity $\left(\mu \mathrm{S} \mathrm{cm}^{-1}\right)$ & 15.20 & 18.60 & 17.02 & 0.75 & 12.60 & 60.60 & 18.93 & 2.25 \\
\hline Temperature $\left({ }^{\circ} \mathrm{C}\right)$ & 20.40 & 28.60 & 23.19 & 1.93 & 16.60 & 29.00 & 22.02 & 2.31 \\
\hline $\mathrm{pH}$ & 6.850 & 7.20 & 7.05 & 0.08 & 6.20 & 7.41 & 6.60 & 0.12 \\
\hline $\mathrm{DO}\left(\mathrm{mgL}^{-1}\right)^{\mathrm{a}}$ & 6.58 & 7.63 & 7.17 & 0.43 & 5.01 & 7.80 & 6.62 & 0.64 \\
\hline Apparent colour (UC) & 24.00 & 53.00 & 38.87 & 6.71 & 0.00 & 254.00 & 18.96 & 15.01 \\
\hline True colour $(\mathrm{UC})^{\mathrm{a}}$ & 0.00 & 25.00 & 7.60 & 7.23 & 0.00 & 23.00 & 0.37 & 1.86 \\
\hline Turbidity (NTU) & 4.00 & 12.00 & 7.40 & 1.79 & 0.00 & 47.00 & 3.37 & 2.48 \\
\hline $\begin{array}{l}\text { Total coliforms (raw water) } \\
\text { (MNP) }\end{array}$ & 2419.60 & 2419.60 & 2419.60 & 0.00 & 0.00 & 2419.60 & 640.36 & 594.22 \\
\hline $\begin{array}{l}\text { Total coliforms (diluted) } \\
\text { (MNP) }\end{array}$ & 3.10 & 28.10 & 13.82 & 7.58 & - & - & - & - \\
\hline E. $\operatorname{coli}(\mathrm{MNP})$ & 7.20 & 93.30 & 22.57 & 24.73 & 0.00 & 2419.60 & 12.81 & 11.44 \\
\hline
\end{tabular}

${ }^{\mathrm{a}}$ For DO, $n=12$; for true colour, $n=25$; for all other parameters $n=30$ 

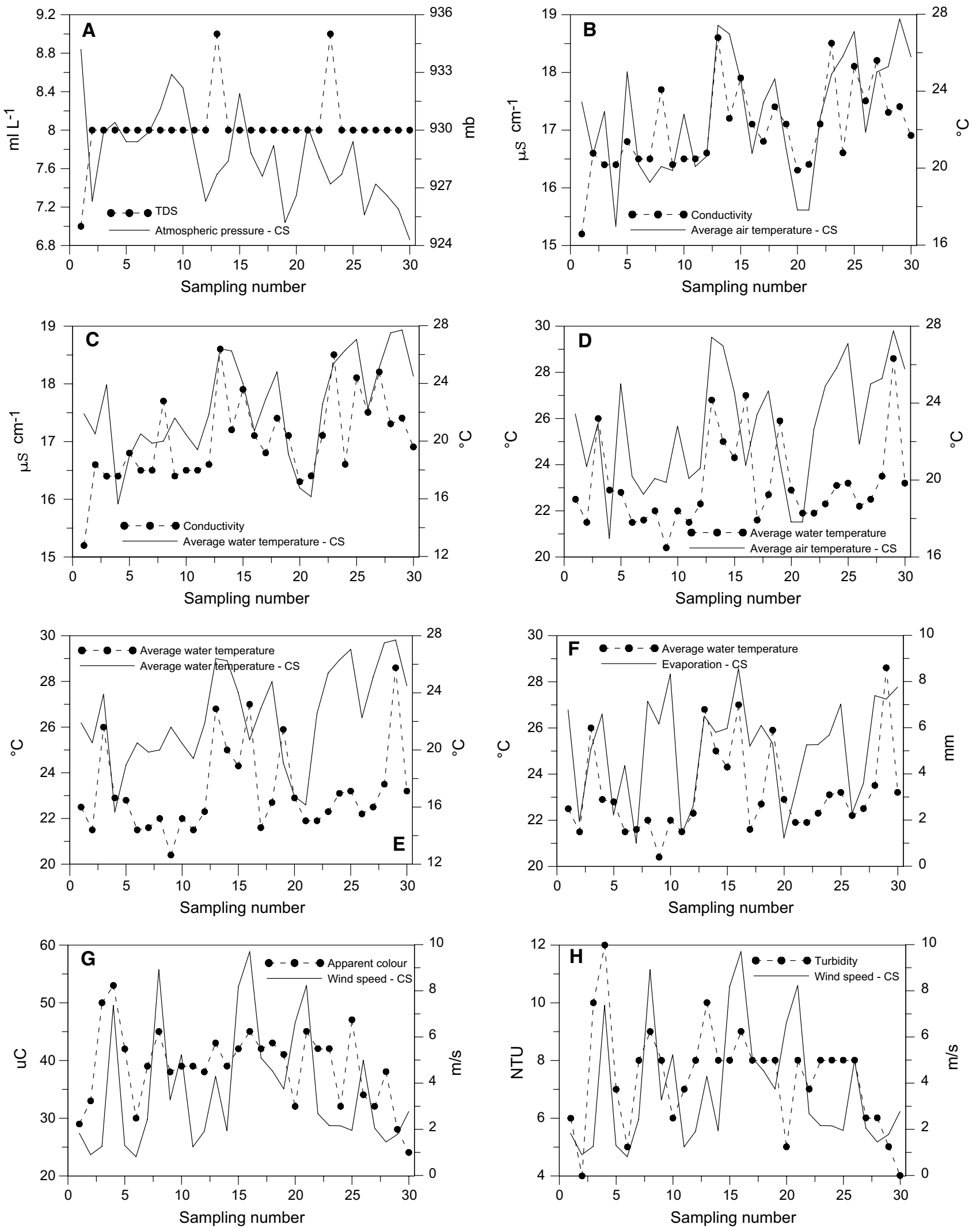
4Fig. 2 Significant correlations between the parameters of the water quality from reservoir and meteorological variables, wherein CS refers to the meteorological parameters obtained at climatological station: a TDS and atmospheric pressure-CS; $\mathbf{b}$ conductivity and average air temperatureCS; c conductivity and average water temperature-CS; $\mathbf{d}$ average water temperature and average air temperature-CS; e average water temperature and average water temperature-CS; $\mathbf{f}$ average water temperature and evaporation-CS; $\mathbf{g}$ apparent colour and wind speed-CS; $\mathbf{h}$ turbidity and wind speed-CS

Portuguese) that follows the rules of the World Meteorological Organization (Table S1). The water temperature-CS, i.e. the temperature of the water observed at the climatological station (CS), and evaporation were measured in a Class A pan, with the aid of a thermocouple ( $T$ type, composed by copper and constantan).

\section{Statistical tests}

The 22 ecological filters were considered identical replica, as they were identically built and filled with the same filter media; they also received the same water at the same time and same flow rate. The average of all water quality and weather variables was calculated for statistical analysis. The water quality and weather variables considered in the statistical analysis are listed in Table S2. Only variables with $n=30$ were considered in the statistical analysis which was carried out by the software Statistica 10.

According to the Shapiro-Wilk and Kolmogorov-Smirnov tests, with a significance level of 5\% cannot reject the normality hypothesis for the meteorological and water quality variables. The correlation $(r)$ and determination $\left(r^{2}\right)$ coefficients were calculated. The coefficient $r$ measures the degree of the relation and the direction (if positive or negative) between two variables. Values were considered significant for $p=0.01-0.05$, very significant for $p=0.001-0.01$ and extremely significant for $p<0.001$.

The calculation of $r^{2}$ was carried out to observe the influence of the weather on water quality parameters. The coefficient $r^{2}$ is defined as the proportion of the variance in the dependent variable that is predictable from the independent variable.

\section{Results and discussion}

\section{Influence of the weather conditions on the Lobo reservoir water quality}

Amongst the basic water quality parameters, TDS, conductivity, $\mathrm{pH}$ and total coliforms from the Lobo reservoir water presented a standard deviation (SD) lower than 1 , showing a low variability of the average values measured. Temperature and turbidity had SD lower than 2 (Table 1), agreeing with what is expected for short periods of data.

Apparent colour, total coliforms (diluted) and E. coli showed higher values of SD for the treated water, but for total coliforms (diluted) and E. coli an isolated episode of poor water quality in the reservoir happened on a single day, increasing the values and thereby modifying the media and causing a variation of the SD value. As it was an isolated episode, it could be assumed to be caused probably by anthropogenic actions. Since its construction in 1936, the Lobo reservoir has been affected by discharge of untreated residential sewage, deforestation, sand mining, tourism and intense sport fishing (Tundisi et al. 2004). For apparent colour, on the 19th collection day, there was a problem with the effluent pipe of filter number 1, which may have caused poor water quality of the effluent of this filter (e.g. turbidity of $47 \mathrm{NTU}, \mathrm{TDS}=23 \mathrm{mg} \mathrm{L}^{-1}$; electrical conductivity $=49.4$ $\mu \mathrm{S} \mathrm{cm}{ }^{-1}$; temperature $=25.9^{\circ} \mathrm{C} ; \mathrm{pH}=7.01$; apparent colour: 254 UC). However, these episodes did not affect the treated water average, as it is shown in Table 1.

The average concentration of total coliforms in the reservoir water (Table 1) was higher than in the ecological filter treated water since the water from the Lobo reservoir cannot be counted as pure (reached the limit of the kit pack-2419.6 MNP). Therefore, dilutions were made in a concentration of 1:500, using Milli-Q water. The maximum E. coli count (2419.60 MNP) in the treated water was associated with the isolated event on a single day in one of the filters and may have been caused by external contamination at the time of sampling.

The survival of pathogens such as coliforms in water increases probably due to higher water temperatures (Hunter 2003). Also, according to Hunter (2003) and Soh et al. (2007) the increase in water temperature, because of the solar radiation (UV) due to ozone layer depletion, leads to a process that could stimulate bacterial activity in aquatic ecosystems. Therefore, for long periods of data, some correlation between solar radiation, water temperature and coliforms concentration is expected. However, due to the short period of this study, this correlation was not observed.

Positive and statistically significant correlations between the electrical conductivity of the Lobo reservoir water and air temperature $(r=0.53 ; p=0.002)$, and water temperature from the Class A pan $(r=0.55 ; p=0.001)$ were observed. The conductivity of the water depends on its ability to diffuse an electric current and is inversely proportional to electrical resistance. This ability is due to the presence of 
Table 2 Coefficients of determination $\left(r^{2}\right)$ between meteorological variables and Lobo's reservoir water quality

\begin{tabular}{|c|c|c|c|c|c|c|}
\hline & $\begin{array}{l}\text { TDS } \\
\left(\mathrm{mgL}^{-1}\right)\end{array}$ & $\begin{array}{l}\text { Conductivity } \\
\left(\mu \mathrm{S} \mathrm{cm}^{-1}\right)\end{array}$ & Water temperature $\left({ }^{\circ} \mathrm{C}\right)$ & $\mathrm{pH}$ & Apparent colour (UC) & $\begin{array}{l}\text { Turbidity } \\
\text { (NTU) }\end{array}$ \\
\hline Average air temperature $\left({ }^{\circ} \mathrm{C}\right)$ & 0.021 & 0.032 & $0.272 *$ & 0.073 & 0.054 & 0.075 \\
\hline Average water temperature $\left({ }^{\circ} \mathrm{C}\right)$ & 0.017 & 0.020 & $0.239 *$ & 0.061 & 0.072 & 0.082 \\
\hline Wind speed $\left(\mathrm{m} \mathrm{s}^{-1}\right)$ & 0.002 & 0.002 & 0.006 & 0.029 & 0.049 & 0.037 \\
\hline Evaporation (mm) & 0.058 & 0.082 & $0.139 *$ & 0.018 & 0.015 & 0.003 \\
\hline Precipitation (mm) & 0.025 & 0.033 & 0.000 & 0.003 & 0.070 & 0.070 \\
\hline Solar radiation $\left(\mathrm{w} \mathrm{m}^{2}\right)$ & 0.001 & 0.003 & 0.035 & 0.009 & 0.061 & 0.042 \\
\hline Insolation (h) & 0.004 & 0.008 & 0.071 & 0.007 & 0.036 & 0.016 \\
\hline Atmospheric pressure (mBar) & 0.003 & 0.000 & $0.149 *$ & 0.076 & 0.039 & $0.142 *$ \\
\hline Relative humidity (\%) & 0.000 & 0.004 & 0.026 & 0.002 & 0.000 & 0.003 \\
\hline
\end{tabular}

$* p$ value $<0.05$

ions, concentration, mobility and valence as well as temperature (Novák 2012). The electrical conductivity of the water increased with increasing air and water temperatures (Fig. 2b, c) as temperature is measured by the degree of agitation of the molecules, either of air or water (Alves and Biudes 2013). Prathumratana et al. (2008) found conductivity to be one of the important parameters for monitoring impacts of climate change on water quality in the lower Mekong River, Indochina.

There were positive and statistically significant correlations between the temperature of water from the reservoir and air temperature $(r=0.45 ; p=0.01)$, water temperature $(r=0.38 ; p=0.04)$ and evaporation $(r=0.41 ; p=0.02)$ as shown in Fig. $2 \mathrm{~d}-\mathrm{f}$, respectively. The water temperature-CS and evaporation were measured in a Class A pan filled with water (water free surface), which heats and evaporates under the prevailing atmospheric conditions, trying to simulate water bodies. Hence, a statistically significant correlation between these variables was expected. The factor that governs all these dynamics is solar radiation, which interacts with a solid, liquid or gaseous surface, increasing the agitation of the molecules and leading to higher water and air temperatures, and increased evaporation (Novák 2012).

Although water sampling was always made at the same point (Fig. 1c), positive and statistically significant correlations were observed between the apparent colour of the reservoir water and the wind speed at $0.5 \mathrm{~m}(r=0.41$; $p=0.024$ ) (Fig. 2g), and between the turbidity of reservoir water and wind speed at $0.5 \mathrm{~m}(r=0.42 ; p=0.02)$ (Fig. 2h). The apparent colour of water is the colour due to colloidal particles or suspended materials. The material in suspension can undergo variations according to the wind speed, stirring the materials in suspension in the reservoir water, and therefore, the correlation between the parameters is positive and significant.

Water aeration and maximum resuspension of particulate and organic matter were observed to be caused by turbulence in the Lobo reservoir on days with high wind velocities (Chalar and Tundisi 1999). This agrees with the positive and statistically significant correlations detected with wind speed and apparent colour and turbidity (Fig. 2g, h).

The atmospheric pressure had a positive and significant correlation between TDS $(r=0.36 ; p=0.05)$ (Fig. 2a); however, reports correlating these two parameters were not found in the literature.

The average air temperature had a statistically significant influence on the temperature of the Lobo water reservoir $\left(r^{2}=0.27, p=0.003\right)$ and the water contained in it $\left(r^{2}=0.24\right.$, $p=0.006$ ) (Table 2). This correlation is in agreement with Murdoch et al. (2000) who state that changes in the temperature of the air influence the temperature of the water, a factor widely discussed when the subject is climatic changes and their effects. In this study, even in a short period of time, the correlation between the parameters was observed, indicating 

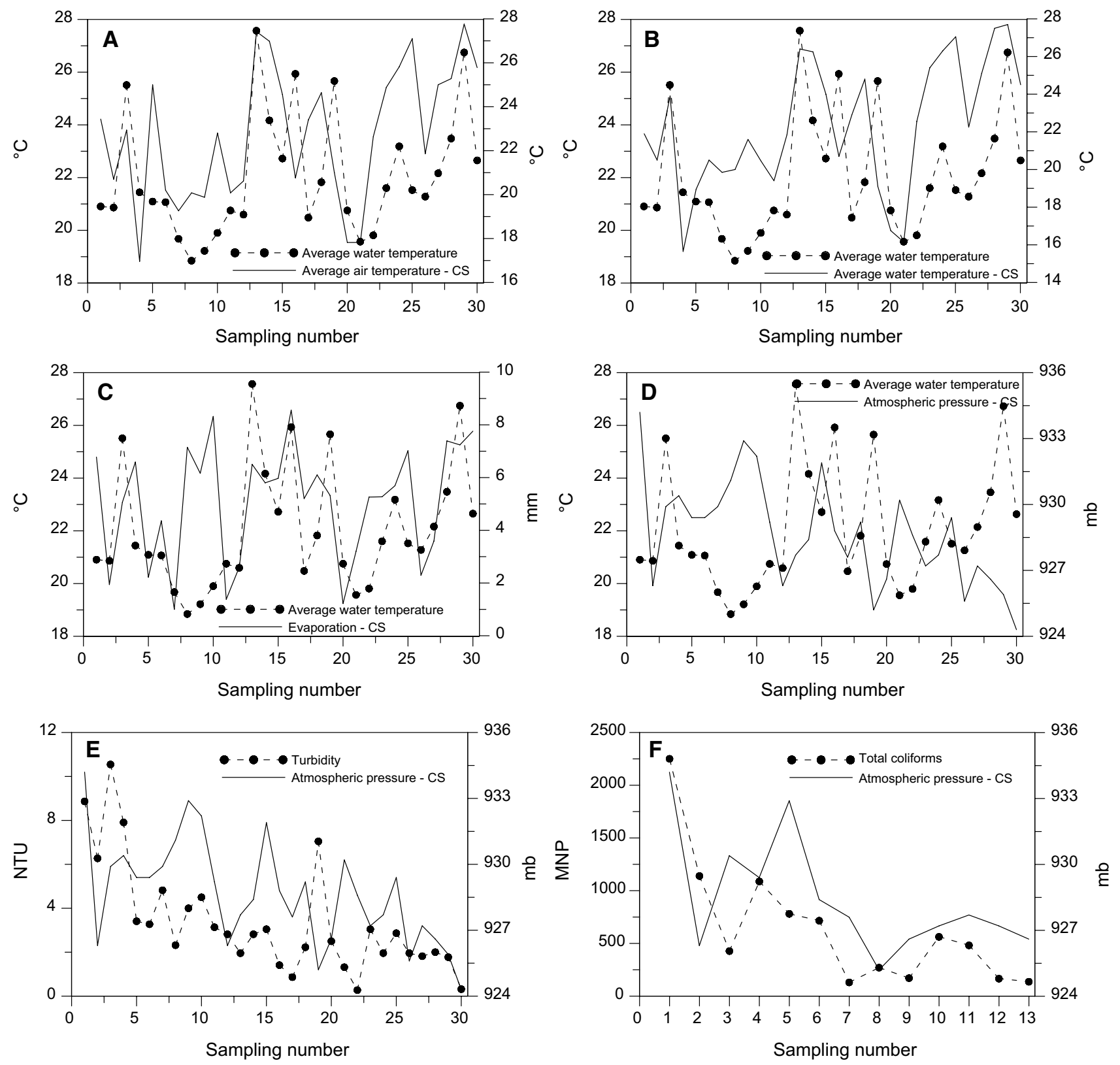

Fig. 3 Significant correlations between the parameters of the water quality from ecological filters and meteorological variables, wherein CS refers to the meteorological parameters obtained at climatological station: a average water temperature and average air temperatureCS; $\mathbf{b}$ average water temperature and average water temperature-CS;

c average water temperature and evaporation-CS; D-average water temperature and atmospheric pressure-CS; e turbidity and atmospheric pressure-CS; $\mathbf{f}$ average total coliforms and atmospheric pressure-CS 
possible effects of climatic changes. According to Delpla et al. (2009), concentration of some parameters such as dissolved organic matter and pathogens can be raised due to temperature increase in water, air and soil.

Evaporation and atmospheric pressure had statistically significant correlations with the reservoir water $\left(r^{2}=0.139\right.$ and $r^{2}=0.142$, respectively); turbidity was also influenced by atmospheric pressure $\left(r^{2}=0.142 ; p=0.04\right)$ (Table 2$)$. According to Samu et al. (2013), the air pressure, temperature and global solar flux are considered the most relevant variables influencing water quality parameters in general, when evaluating lakes.

\section{Influence of weather conditions on the water treated by ecological filters}

For the water quality parameters from the effluent water of the ecological filters, the SD showed similar results from the water of the Lobo reservoir. The average apparent colour, total coliforms and $E$. coli of the 22 filters had high SD due to variations of the reservoir water quality during the collection period.

Considering all the evaluated parameters, five correlations were statistically significant. Similarly to the reservoir water, there were positive and very significant correlations between the average water temperature of the effluent of ecological filters and the air temperature $(r=0.52 ; p=0.003)$, and water temperature of the reservoir $(r=0.49 ; p=0.006)$ (Fig. 3a, b). The average temperature of the effluents of the ecological filters showed a positive and significant correlation with evaporation ( $r=0.37 ; p=0.04$ ) as shown in Fig. 3c.

The atmospheric pressure (Fig. 3d, e) had significant correlation between water temperature from the effluent of the ecological filters $(r=0.39 ; p=0.03)$ and turbidity $(r=0.37$; $p=0.04$ ), negative and positive, respectively. Also, there was a positive and significant correlation between total coliforms and atmospheric pressure $(r=0.69 ; p=0.009)$ (Fig. 3f). A study conducted to identify the impacts of meteorological factors on the water quality of membrane bioreactors and phytoremediation system found significant positive correlation between air pressure and turbidity for both treatment systems, and a slightly negative correlation with total coliform concentration for phytoremediation system (Andleeb and Hashmi 2017). These correlations indicate that there is an impact of climate on water and wastewater treatment systems to be considered as part of the projects on water and wastewater treatment plants.

Although the present study considered a short period of time (i.e. 4 months), it shows that temperature changes have great influence on parameters of water treated by ecological filters. It indicates that over time these changes in temperature and climate can greatly influence the treatment processes. Therefore, it is suggested to run similar investigation considering a long-term operation to capture seasonal variations. This would also help to evaluate the maximum operation period and cleaning process since the filters were not clogged during our research.

During this study, the results of water quality indicated that the treated water was within the standard of potability from Brazil (Brasil 2011), but needs to be disinfected to totally remove coliforms.

\section{Conclusion}

Eight positive and statistically significant correlations were found between the water from the Lobo reservoir and weather variables: (1) TDS and air pressure, (2) conductivity and average air temperature, (3) conductivity and average water temperature, (4) average water temperature and average air temperature, (5) average water temperature and average water temperature, (6) average water temperature and evaporation, (7) apparent colour and wind speed, and (8) turbidity and wind speed. One negative statistically significant correlation was found between atmospheric pressure and TDS.

Five positive and significant correlations between average water quality parameters of the 22 ecological filters and average weather variables were found: (1) effluent filter water temperature and air temperature; (2) effluent filter water temperature and average water temperature; (3) effluent filter water temperature and evaporation; (4) effluent turbidity and atmospheric pressure; and (5) total coliforms of the effluent filter water and atmospheric pressure. One negative and significant correlation occurred between atmospheric pressure and water temperature from effluent of the ecological filters.

Statistical analyses showed that in addition to the correlations between the weather conditions and water quality parameters, some meteorological variables influenced the variability of some parameters of filtered water quality. 
These results indicate that variations in the air temperature, water and atmospheric pressure can affect the filtered water quality. So the possible increase in global air temperature may influence treatment performance. The climatic parameters of an area should be considered together with the water quality of the source to assist design and operation of drinking water treatment processes.

Acknowledgements This work was supported by the São Paulo Research Foundation, FAPESP (Project Number n. 2012/21981-7). Dr. Caroline Moço Erba Pompei was supported by the São Paulo Research Foundation, FAPESP through the scholarship n. 2011/21666-1. The authors wish to thank Dr Edson Pereira Tangerino for designing the system of the ecological filters.

Open Access This article is distributed under the terms of the Creative Commons Attribution 4.0 International License (http://creativeco mmons.org/licenses/by/4.0/), which permits unrestricted use, distribution, and reproduction in any medium, provided you give appropriate credit to the original author(s) and the source, provide a link to the Creative Commons license, and indicate if changes were made.

\section{References}

Alves EDL, Biudes MS (2013) Method for determining the footprint area of air temperature and relative humidity. Acta Sci Technol 35(2):187-194

Andleeb KB, Hashmi I (2017) Effects of selective meteorological parameters on water quality of wastewater treatment systems. Pak J Meteorol 14(27):13-23

Bellamy WD, Hendricks DW, Logsdon GS (1985) Slow sand filtration: influences of selected process variables. J AWWA 77(12):62-66

Brasil (2011) Ministério da Saúde. Portaria no 2.914, de 12 de dezembro de 2011. Dispõe sobre os procedimentos de controle e de vigilância da qualidade da água para consumo humano e seu padrão de potabilidade. Diário Oficial da União [da] República Federativa do Brasil. Seção 1, p 26

Calijuri MC, Tundisi JG (1990) Limnologia Comparada das Represas do Lobo (Broa) e Barra Bonita-Estado de São Paulo: Mecanismos de Funcionamento e Bases para o Gerenciamento. Rev Brasil Biol 50(4):893-913

Campos LC, Su MFJ, Graham NJD, Smith SR (2002) Biomass development in slow sand filters. Water Res 36(18):4543-4551

Chalar G, Tundisi JG (1999) Main processes in the water column determined by wind and rainfall at Lobo (Broa) Reservoir. Implications for phosphorus cycling. In: Theoretical reservoir ecology and its applications. Backhuys Publishers, São Carlos, Brazil, pp 53-65
Delpla I, Jung A-V, Baures E, Clement M, Thomas O (2009) Impacts of climate change on surface water quality in relation to drinking water production. Environ Int 35:1225-1233

Erba CM, Tangerino EP, Isique WD, Campos LC (2014) Removal of anti-inflammatory compounds by ecological filtration. In: Nakamoto N, Graham N, Cins MR, Gimbel R (eds) Progress in slow sand and alternative biofiltration process, 1 edn. IWA Publishing, pp 147-152

Fukushima T, Kaminishi H, Matsushig K, Harasawa H (1998) Influence of meteorological conditions on the water quality of a shallow Eutrophic lake. J Jpn Soc Water Environ 21(3):180-187

Haarhoff J, Cleasby JL (1991) Biological and physical mechanisms in slow sand filtration. In: Logsdon GS (ed) Slow sand filtration, vol 1. American Society of Civil Engineers. New York, NY pp, pp 19-68

Huisman L, Wood WE (1974) Slow sand filtration. World Health Organization, Geneva, pp 1-89

Hunter PR (2003) Climate change and waterborne and vector-borne disease. J Appl Microbiol 94:37S-46S

Jones RN, Page CM (2001) Assessing the risk of climate change on the water resources of the Macquarie River catchment. In: Integrating models for natural resources management across disciplines, part 2. Issues and scales. (Proceedings of MODSIM 2001-international congress on modelling and simulation) modelling and simulation society of Australia and New Zealand, Canberra, Australia, pp 673-678

Li J, Zhou Q, Campos LC (2018) The application of GAC sandwich slow sand filtration to remove pharmaceutical and personal care products. Sci Total Environ 625:1182-1190

Mujere N, Moyce W (2017) Climate change impacts on surface water quality. In: Ganpat W, Isaac W (eds) Environmental sustainability and climate change adaptation strategies. IGI Global, Hershey, pp 322-340

Murdoch PS, Baron JS, Miller TL (2000) Potential effects of climate change on surface-water quality in North America. J Am Water Resour Assoc 36(2):347-366

Nakamoto N (2008) Produza você mesmo uma água saborosa—sistema de purificação ecológica-revendo a tecnologia de produção de água potável. Ferrari, São Paulo

Nakamoto N (2011) Idea of ecological purification system for drinking water comes from Broa Resevoir. Oecol Aust 15(3):709-713

Novák V (2012) Evapotranspiration in the soil-plant-atmosphere system. Springer, Dordrecht

Pompei CME, Ciric L, Canales M, Karu K, Vieira EM, Campos LC (2017) Influence of PPCPs on the performance of intermittently operated slow sand filters for household water purification. Sci Total Environ 581-582:174-185

Prathumratana L, Sthiannopkao S, Kim KW (2008) The relationship of climatic and hydrological parameters to surface water quality in the lower Mekong river. Environ Int 34(6):860-866 
Rajib MA, Rahman MM, McBean EA (2012) Evaluating technological resilience of small drinking water systems under the projected changes of climate. J Water Clim Change 3(2):110-124

Rodríguez MP, Matsumura-Tundisi T (2000) Variation of density, species composition and dominance of rotifers at a shallow tropical reservoir (Broa Reservoir, SP, Brazil) in a short scale time. Revista Brasileira de Biologia 60(1):01-09

Samu A, Csépe Z, Bárány-Kevei I (2013) Influence of meteorological variables to water quality in five lakes over the aggtelek (Hungary) and slovak karst regions-a case study. Acta Carsol 42(1):121-133
Soh YC, Roddick F, van Leeuwen J (2007) The future of water in Australia: the potential effects of climate change and ozone depletion on Australian water quality, quantity and treatability. Environmentalist 28(2):158-165

Tundisi JG, Matsumura-Tundisi T, Arantes JD Jr, Tundisi JEM, Manzini NF, Ducrot R (2004) The response of Carlos Botelho (Lobo, Broa) reservoir to the passage of cold fronts as reflected by physical, chemical, and biological variables. Braz J Biol 64(1):177-186

Whitehead PG, Wilby RL, Battarbee RW, Kernan M, Wade AJ (2009) A review of the potential impacts of climate change on surface water quality. Hydrol Sci J 54(1):101-123 